PR-37

\title{
THE STUDY OF THE ANTIOXIDANT ACTIVITY OF 2-AMINOTHIAZOLES CONTAINING A DITERPENE FRAGMENT BY CHEMILUMINESCENCE
}

\author{
$\underline{\text { N. Khusnutdinova, }}{ }^{1}$ S. Meshcheryakova, ${ }^{1}$ R. Sultanova ${ }^{2}$ \\ ${ }^{1}$ Bashkir State Medical University, 3 Lenina St, , Ufa, 450008, Russia; \\ ${ }^{2}$ Ufa Institute of Chemistry of the Russian Academy of Sciences, Ufa Federal Scientific Centre, Ufa, 71 \\ Oktyabrya Ave, 450054, Russia. \\ E-mail: neilyhusnutdinova@yandex.ru
}

\begin{abstract}
Presently the focus is on developing both synthetic and natural compounds like antioxidants that act at different levels and that can be possibly used to reduce damage caused by oxidative stress. Among these, biologically important compounds with a wide spectrum of action (antitumor, antioxidant and antioxidant activity) are aminothiazoles.

The work uses new derivatives of maleopimaric acid (MPA): $\alpha$-bromketone $\mathbf{1}$ and 2aminothiazole, containing a diterpene fragment 2-11 (Scheme 1), which were synthesized by us earlier ${ }^{1}$. Using the method of luminol-dependent chemiluminescent analysis it is revealed that the tested compounds under investigation exhibit antioxidant properties in model test systems, where the processes of reactive oxygen species formation, lipid peroxidation, and cell phagocytosis of the blood are induced.
\end{abstract}

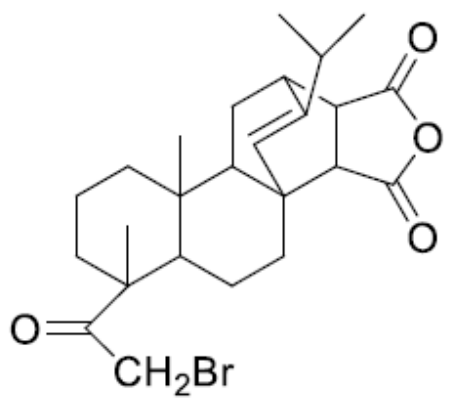

1

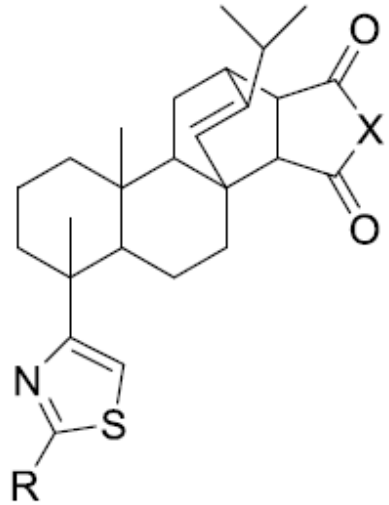

2-11

2: $\mathrm{X}=\mathrm{O}, \mathrm{R}=\mathrm{NH}_{2} ; \mathbf{3}: \mathrm{X}=\mathrm{O}, \mathrm{R}=\mathrm{NH}-\mathrm{All} ; \mathbf{4}: \mathrm{X}=\mathrm{O}, \mathrm{R}=\mathrm{NH}-\mathrm{Ph} \mathbf{5}: \mathrm{X}=\mathrm{O}, \mathrm{R}=\mathrm{NH}-\mathrm{O}-\mathrm{Tol} ; \mathbf{6}: \mathrm{X}=\mathrm{O}, \mathrm{R}=\mathrm{NH}-\mathrm{Ac}$

7: $\mathrm{X}=\mathrm{O}, \mathrm{R}=\mathrm{Me} ; \mathbf{8}: \mathrm{X}=\mathrm{N}-\mathrm{Ph}, \mathrm{R}=\mathrm{NH}_{2} ; \mathbf{9}: \mathrm{X}=\mathrm{N}-\mathrm{Ph}, \mathrm{R}=\mathrm{NH}-\mathrm{All} ; \mathbf{1 0}: \mathrm{X}=\mathrm{NH}-\mathrm{Ph}, \mathrm{R}=\mathrm{NH}-\mathrm{Ph} ; \mathbf{1 1}: \mathrm{X}=\mathrm{N}-\mathrm{Ph}, \mathrm{R}=\mathrm{NH}-\mathrm{O}-\mathrm{Tol}$

Scheme 1. Structural formulas of new derivatives of maleopimaric acid 2-11

It was found that the synthesized compounds 1-11 have antioxidant effects, expressed to different degrees. These compounds reduce the light sum of the glow and lengthen the latent period, which correlates with the antioxidant activity of the blood. ${ }^{2,3}$

We observed that, that some compounds, for example, 2-5, which equally suppressed ROS production and LPO processes in the test model systems, in lower concentrations stimulated an oxygendependent explosion in phagocytes more, which indicates their dual effect on the activation of oxygendependent metabolism of blood phagocytes. The findings confirm the prospect of further study of newly synthesized derivatives of 2-aminothiazole.

\section{References}

1. Sultanova R. M., Lobov A. N., Shumadalova A. V., Meshcheryakova S. A., Zileeva Z. R., Khusnutdinova N. S., Vakhitov V. A., Vakhitova Y. V. Natural Product Research, published on line https://doi.org/10.1080/14786419.2019.1648459.

2. Martusevich A. K., Karuzin K. A., Samoilov A. S. (2018). Bioradicals and Antioxidants. 5, 5-23

3. Farkhutdinov R. R., Likhovsky V. A. (1995). Chemiluminescent methods for the study of free radical oxidation in biology and medicine (BSMU, Ufa, pp.1-92. 